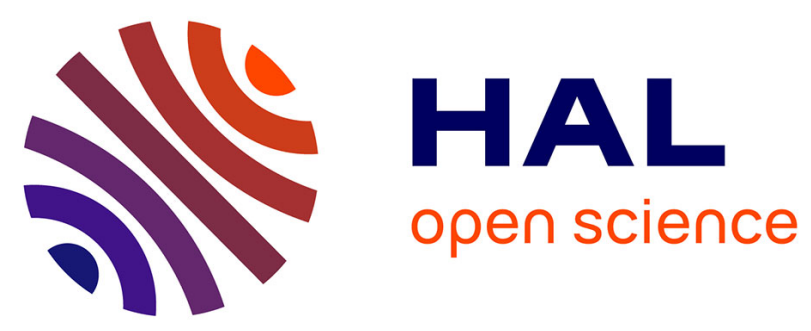

\title{
Observations of postglacial sea-level rise in northwest European traditions
}

\author{
Patrick Nunn, Axel Creach, W. Roland Gehrels, Sarah Bradley, Ian Armit, \\ Pierre Stéphan, Fraser Sturt, Agnès Baltzer
}

\section{- To cite this version:}

Patrick Nunn, Axel Creach, W. Roland Gehrels, Sarah Bradley, Ian Armit, et al.. Observations of postglacial sea-level rise in northwest European traditions. Geoarchaeology: An International Journal, 2021, 10.1002/gea.21898 . hal-03485934

\section{HAL Id: hal-03485934 \\ https://hal.science/hal-03485934}

Submitted on 3 Jan 2022

HAL is a multi-disciplinary open access archive for the deposit and dissemination of scientific research documents, whether they are published or not. The documents may come from teaching and research institutions in France or abroad, or from public or private research centers.
L'archive ouverte pluridisciplinaire HAL, est destinée au dépôt et à la diffusion de documents scientifiques de niveau recherche, publiés ou non, émanant des établissements d'enseignement et de recherche français ou étrangers, des laboratoires publics ou privés. 


\title{
Observations of postglacial sea-level rise in northwest European traditions
}

\author{
Patrick D. Nunn ${ }^{1 *}$, Axel Creach ${ }^{2}$, W. Roland Gehrels ${ }^{3}$, Sarah L. Bradley ${ }^{4}$, lan Armit $^{5}$, Pierre \\ Stéphan ${ }^{6}$, Fraser Sturt ${ }^{7}$, Agnès Baltzer ${ }^{8}$ \\ ${ }^{1}$ School of Law and Society, University of the Sunshine Coast, Maroochydore, Queensland, Australia \\ ${ }^{2}$ UFR de Géographie et Aménagement, Sorbonne Université, Paris, France \\ ${ }^{3}$ Department of Environment and Geography, University of York, Heslington, York, United Kingdom \\ ${ }^{4}$ Department of Geography, University of Sheffield, Sheffield, United Kingdom \\ ${ }^{5}$ Department of Archaeology, University of York, Heslington, York, United Kingdom \\ ${ }^{6}$ Institut Universitaire Européen de la Mer, Université de Bretagne Occidentale, Brest, France \\ ${ }^{7}$ Department of Archaeology, University of Southampton, Southampton, United Kingdom \\ ${ }^{8}$ Institut de Géographie et d'Aménagement Régional, Université de Nantes, Nantes, France \\ ${ }^{*}$ Corresponding author \\ Email: pnunn@usc.edu.au
}

\begin{abstract}
In pre-literate contexts, diverse knowledge was accumulated, processed and communicated orally. Recent research demonstrates that observations of memorable events were transferred in this way for sometimes thousands of years. Much of this information was eventually written down to reach literate audiences, which commonly judge such 'myths and legends' to be cultural inventions rather than ancient memories. This study examines 15 'submergence stories' from northwest European coasts and argues that they plausibly represent memories of postglacial sealevel rise which, in this region, was spatially and temporally variable owing to the interaction of sea-level rise with global isostatic adjustment.

This study combines culture history and knowledge of earth rheology to argue that memories of the effects of postglacial land submergence in northwest Europe have endured for $5000-15,000$ years. This requires a longevity of memory, orally communicated, that will surprise many. It also points to the likelihood that oral cultures in other parts of the world may have preserved observations of memorable events in a similar form that scientists today might benefit from trying to understand better.
\end{abstract}

\section{INTRODUCTION}

For most of modern-human history, information has been communicated orally, typically from one generation to another, focused on a group's history and understanding of the part of the world it occupied. The information included details about how to survive, especially in comparatively resource-sparse contexts or those where climate variability periodically created conditions (such as drought) causing livelihood exigency. This information also contained details about landscape, its possibilities and constraints, and the ways it had been seen to change; memories of catastrophic events (like volcanic eruptions or tsunamis); as well as 'creation stories' 
that cemented group identity and attachment to place (Tonkin, 1992, Basso, 1996, Kelly, 2015, Nunn, 2018).

The advent/spread of literacy not merely displaced orality but also led to the subordination of its value, its breadth and depth. Literate people invariably judge oral tales (contemporary and ancient) as fictional, dismissing their substance as having any practical worth, largely because this cannot be readily measured using the yardsticks of modern (western) science (Ong, 1982). Yet in pre-literate (oral) societies, especially those in which a group's future survival was deemed dependent on each generation acquiring all the knowledge amassed by their forebears, such information was commonly expressed in memorable ways, designed to encourage its uptake by younger members of the group. So knowledge was communicated in narrative - sometimes spoken, sometimes sung or danced - and often involved the activities of fabulous beings with superhuman abilities, all designed to aid memorability and replication fidelity (Vansina, 1985, Barber and Barber, 2004, Nunn, 2018).

Several studies have shown that ancient stories not only have demonstrable meaning, typically based on eyewitness observations of memorable natural phenomena (Vitaliano, 1973, Piccardi and Masse, 2007), but also that they were elements of systems of (sub-global, place-specific) understanding that match contemporary global (western) science in terms of their breadth and depth (eg Stewart et al., 2004, Sugiyama et al., 2020). Through determining the dates of some such phenomena, it has proved possible to assign (minimum) ages to the associated stories, something which has demonstrated a largely unsuspected longevity for many - perhaps more than ten millennia for some (Hamacher and Goldsmith, 2013, Nunn and Reid, 2016, Matchan et al., 2020).

In Australia, which has been mostly occupied by Indigenous (Aboriginal) groups descended from migrants who arrived on this uninhabited continent about 70,000 years ago, the existence of numerous ancient stories in extant traditions has been attributed to this unusually long cultural continuity and the associated absence of contact with other groups until very recently (Ross, 1986). In particular, from more than twenty places all along the coast of Australia, Aboriginal stories have been collected that recall a time when the ocean surface was lower, the coastline further seawards, and when what are now offshore islands were contiguous with the mainland. Stories recall what these now-submerged lands looked like, what resources and events were linked with them, as well as the process of their (generally gradual) submergence and the responses of affected peoples to this (Nunn and Reid, 2016, Roberts et al., 2019, Nunn, 2020). This study presents an analysis of similar 'submergence stories' from northwest Europe, the distribution of which is attributable to the postglacial sea-level history of this region. The study presented here is therefore somewhat innovative in linking geography to both culture history and earth rheology.

The next section (Section 2) gives more detail of the postglacial changes in the land surface across the study region. This is followed by Section 3 in which 15 stories are summarized, each considered to plausibly recall ancient observations of times when sea level was lower than today and the effects of its subsequent rise. Using site-specific information about postglacial sea-level 
changes in various parts of the region, approximate minimum ages for these stories are given in Section 4 and compared to those from Australia (raw data is given in SI1). Section 5 discusses the meaning of these stories and explores globally-relevant implications of this study.

\section{CONTEXT}

The stories presented and analysed below come from that part of the continental margin in northwest Europe which formed a largely contiguous landmass during the coldest times of the last ice age (Last Glacial Maximum or LGM) when the average sea level here was about 120 metres lower than today (Figure 1), shallower along northern coastlines depressed by land ice. This section looks at the postglacial history of sea-level rise and the uneven influence of glacialisostatic adjustment (GIA) within this region.

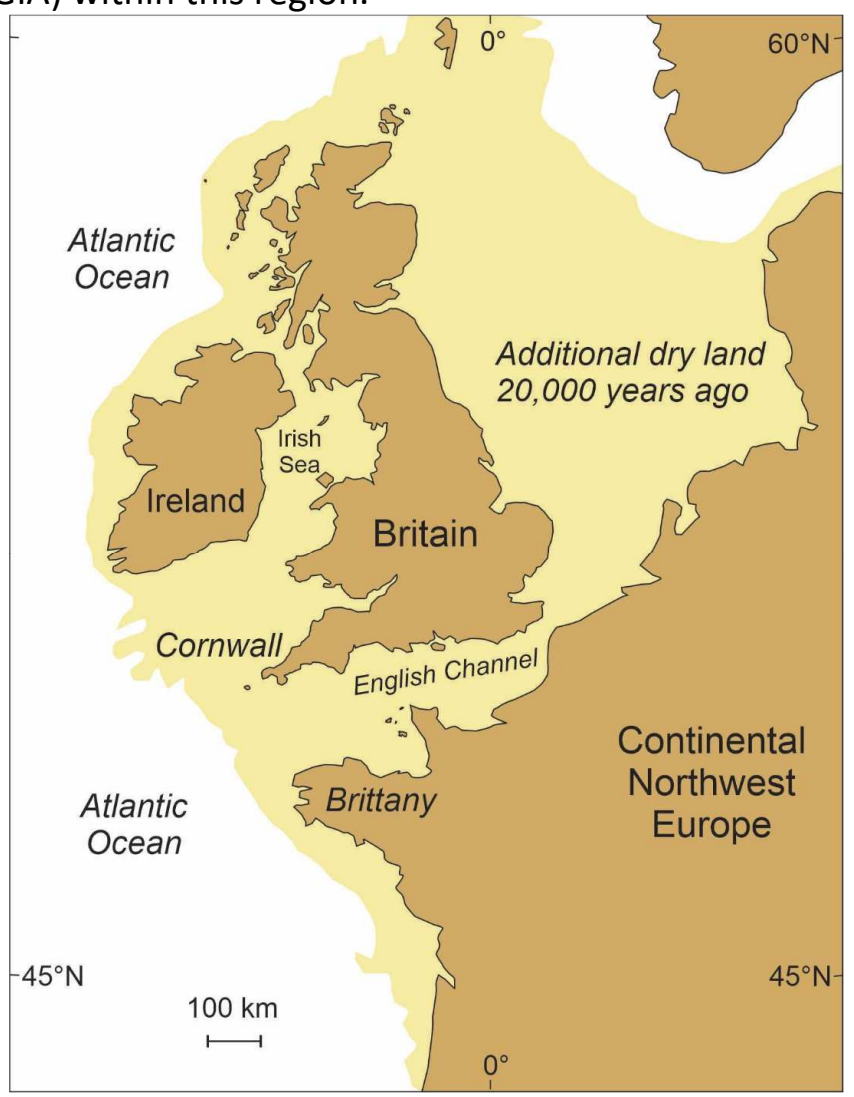

Figure 1. Northwest Europe showing the additional dry land that existed 20,000 years ago during the Last Glacial Maximum and which was progressively submerged in its aftermath (after Gaffney et al., 2009).

During the LGM, most of what are now the British Isles were joined to continental Europe although ice sheets covered Ireland, Scotland and (most of) Wales and the northern half of England, and filled the Irish Sea at this time (Clark et al., 2012). After the LGM ended around 17,000 years ago, temperatures began rising, land ice began melting, and sea level rose in consequence. Yet in such 'near-field' regions, the observed course of postglacial (late Pleistocene 
and Holocene) sea-level change was spatially variable, a result of the interplay between rising water levels (barystatic sea-level rise - Gregory et al., 2019) and vertical changes in the Earth's crust, explainable both by the isostatic rebound of previously ice-covered areas and by the collapse of peripheral crustal bulges formed when lithospheric material was alternately squeezed into them when ice sheets formed and moved back as ice sheets melted (Milne et al., 2009, Gehrels, 2010).

Figure 2A shows relative land-level changes within the last one thousand years (Shennan et al., 2012). The areas that had been covered by the thickest ice during the LGM are those which have been rising fastest and where (relative) sea level is currently falling. In central and southern Scotland, for example, several places have been rising at $>1.0 \mathrm{~mm} /$ year relative to sea level. At the other extreme, places in southwest England and Brittany are being submerged the fastest, Penzance and Brest being submerged at rates of $0.7 \mathrm{~mm} /$ year (Garcia-Artola et al., 2018).

These movements have clear implications for the presence of 'submergence stories' (located by plus signs in Figure 2B). In places where the land has been rising and sea level falling for several millennia, former settlements have emerged and, as is well documented in Norway and mainland Scotland (Smith et al., 2010, Draganits et al., 2015), are today often several kilometres inland from their former coastal locations. In contrast, in places where the land is subsiding and relative sea-level rise is fastest - in this case because of the collapse of peripheral bulges and hydroisostatic loading of continental shelves - stories about submergence are more common, as is clear from those off the coast of Cornwall and Wales (stories 7-10 in Section 3). 

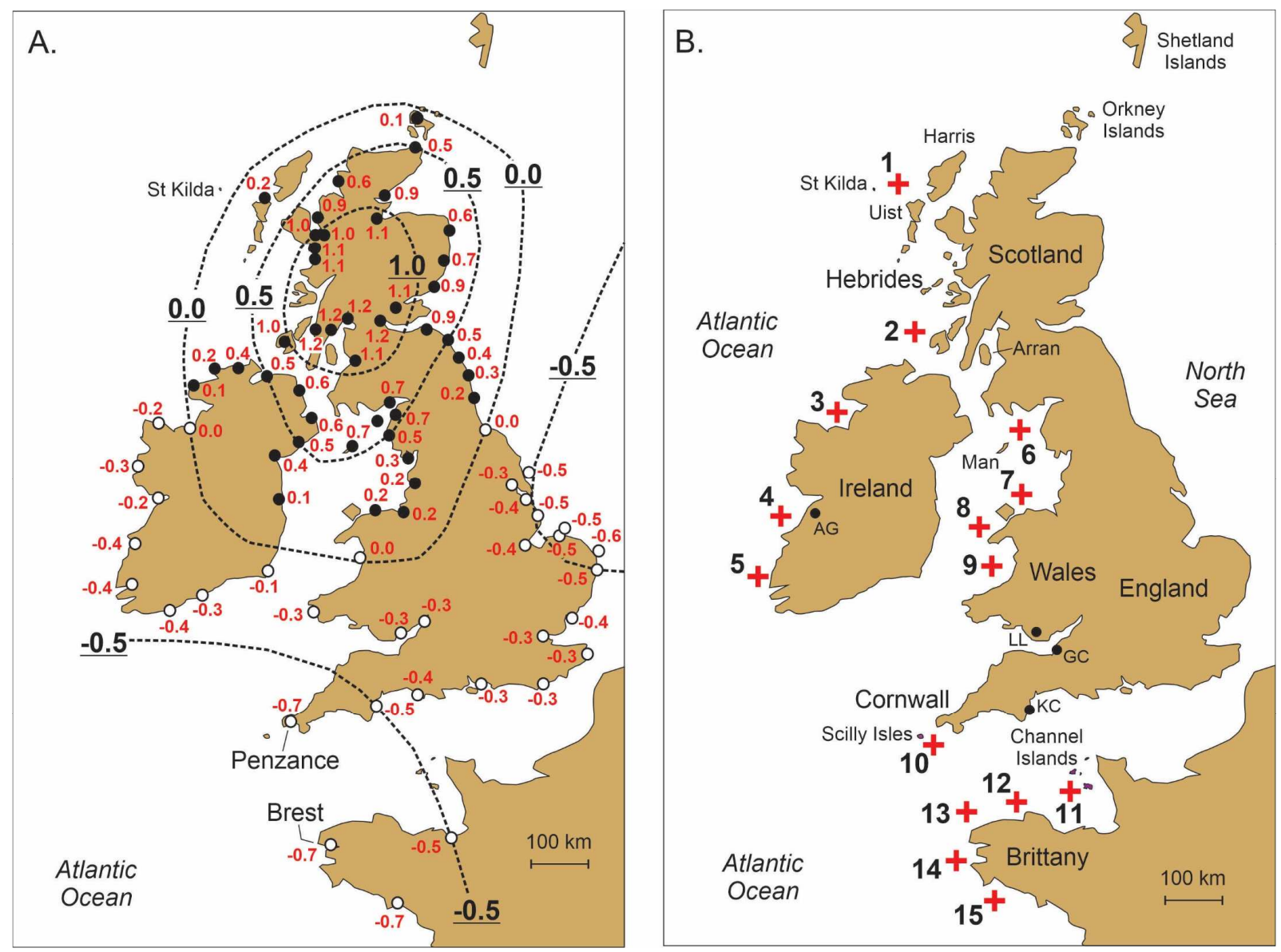

Figure 2. A: Rates (mm/year) of late Holocene relative sea- and land-level changes. Rates for the British Isles are from Kuchar et al. (2012). Rates for Brittany were computed from the ICE 6G GIA model (Peltier et al., 2015). Black-filled circles signify sites that are emerging (the land is rising relative to sea level); open (unfilled) circles signify sites that are being submerged (the land is sinking relative to sea level). B: Locations of the 15 groups of stories presented in Section 3.

\section{STORIES RECALLING COASTAL DROWNING}

Traditions that recall coastal submergence consistent with postglacial sea-level rise have been identified in 15 places along the coasts of the British Isles and northwest France (Figure 2B and Table 1). Each tradition is considered authentic, place-specific and having a history which suggests it has its origins in ancient oral stories created by particular pre-literate groups of people living in the places to which the stories refer. Stories of other submerged places were also considered (like the Gwerddonau Llion (Green Isles) of southwest Wales, and Occismor in Brittany) yet literature review found that the available details of these stories were too diffuse and geographical information too vague to adequately argue for their inclusion in what is considered a robust data set. 


\begin{tabular}{|c|c|c|c|c|}
\hline $\begin{array}{l}\text { Number on } \\
\text { Figure 2B map }\end{array}$ & Area & Location & Outline of stories & Main source/s \\
\hline 1 & $\begin{array}{l}\text { Outer Hebrides, } \\
\text { Scotland }\end{array}$ & $\begin{array}{l}\text { Between Harris/Uist and St } \\
\text { Kilda islands }\end{array}$ & $\begin{array}{l}\text { A warrior used to hunt with hounds on } \\
\text { what is now the sea floor between } \\
\text { these islands }\end{array}$ & $\begin{array}{l}\text { Martin (1753); } \\
\text { Maclean (1972) }\end{array}$ \\
\hline 2 & $\begin{array}{l}\text { Irish Sea } \\
\text { (northern part) }\end{array}$ & $\begin{array}{l}\text { Isle of Staffa (Inner Hebrides) } \\
\text { and Arran to Giant's } \\
\text { Causeway (Co. Antrim) }\end{array}$ & $\begin{array}{l}\text { Stories about how Fionn mac } \\
\text { Cumhaill (Finn McCool) made a mole } \\
\text { (causeway) uniting Scotland and } \\
\text { Ireland; how he crossed what is now } \\
\text { the Irish Sea }\end{array}$ & $\begin{array}{l}\text { Henderson (1905); } \\
\text { Andrews (1913: 90-91) }\end{array}$ \\
\hline 3 & $\begin{array}{l}\text { Co. Mayo, } \\
\text { Ireland }\end{array}$ & $\begin{array}{l}\text { Submerged part of Sligo } \\
\text { Town }\end{array}$ & $\begin{array}{l}\text { Fisherfolk report seeing submerged } \\
\text { buildings }\end{array}$ & $\begin{array}{l}\text { Wood-Martin }(1882, \\
1902)\end{array}$ \\
\hline 4 & $\begin{array}{l}\text { Co. Clare, } \\
\text { Ireland }\end{array}$ & $\begin{array}{l}\text { Submerged land of } \\
\text { Kilstuithin (Kilstapheen) off } \\
\text { Lahinch }\end{array}$ & $\begin{array}{l}\text { This land, perhaps once part of } \\
\text { Lahinch Town, was 'drowned' } \\
\text { (perhaps in a flood, perhaps by a } \\
\text { Druid) }\end{array}$ & $\begin{array}{l}\text { Westropp }(1908,1912- \\
13: 250-1)\end{array}$ \\
\hline 5 & $\begin{array}{l}\text { Co. Kerry, } \\
\text { Ireland }\end{array}$ & Ballyheigue Bay & $\begin{array}{l}\text { Stories tell of an island submerged by } \\
\text { a mermaid's father; remains marked by } \\
\text { Cantillon's Rocks }\end{array}$ & $\begin{array}{l}\text { Croker (1844: 139); } \\
\text { Westropp (1912-13: } \\
\text { 249) }\end{array}$ \\
\hline 6 & Isle of Man & $\begin{array}{l}\text { (1) Submerged/floating } \\
\text { islands, (2) former land } \\
\text { connection with English } \\
\text { mainland }\end{array}$ & $\begin{array}{l}\text { Stories of times when Isle of Man } \\
\text { was connected to Scotland, fisherfolk } \\
\text { bring up evidence of former } \\
\text { habitations }\end{array}$ & $\begin{array}{l}\text { Welch (1836); } \\
\text { Gill (1932) }\end{array}$ \\
\hline 7 & $\begin{array}{l}\text { Conway } \\
\text { (Conwy), north } \\
\text { Wales }\end{array}$ & $\begin{array}{l}\text { Sea floor off Conway coast } \\
\text { between Penmaenmawr and } \\
\text { the Great Orme's Head }\end{array}$ & $\begin{array}{l}\text { A rise of sea level permanently } \\
\text { submerged the lands (Tyno Helig) of } \\
\text { Prince Helig }\end{array}$ & $\begin{array}{l}\text { North (1957); } \\
\text { Curran (2000) }\end{array}$ \\
\hline 8 & $\begin{array}{l}\text { Gwynedd, north } \\
\text { Wales }\end{array}$ & $\begin{array}{l}\text { Sea floor off coast including } \\
\text { the ruins of Caer (Castle) } \\
\text { Arianrhod }\end{array}$ & $\begin{array}{l}\text { A rise of sea level permanenly } \\
\text { submerged these lands, commonly in } \\
\text { punishment for their inhabitants' } \\
\text { misdeeds }\end{array}$ & $\begin{array}{l}\text { Wilson (1870: 334); } \\
\text { North (1957) }\end{array}$ \\
\hline 9 & $\begin{array}{l}\text { Ceredigion, } \\
\text { west Wales }\end{array}$ & Cardigan Bay (unspecified) & $\begin{array}{l}\text { A rise in sea level permanently } \\
\text { submerged these lands (Maes } \\
\text { Gwyddno - The Plain of [King] } \\
\text { Gwyddno) and the city of Cantre'r } \\
\text { Gwaelod }\end{array}$ & $\begin{array}{l}\text { Bromwich (1950); } \\
\text { North (1957); } \\
\text { Doan (1981); } \\
\text { Jones \& Jones (2001); }\end{array}$ \\
\hline 10 & $\begin{array}{l}\text { Cornwall/Scilly } \\
\text { Isles, Southwest } \\
\text { England }\end{array}$ & $\begin{array}{l}\text { either off Land's End } \text { or } \\
\text { within Scilly archipelago }\end{array}$ & $\begin{array}{l}\text { A rise in sea level permanently } \\
\text { submerged the land of Lyonesse }\end{array}$ & $\begin{array}{l}\text { Borlase (1756); } \\
\text { Crawford (1929); } \\
\text { Charman et al. (2016) }\end{array}$ \\
\hline 11 & Channel Islands & mostly Jersey Island & $\begin{array}{l}\text { Stories tell that it was formerly } \\
\text { possible to walk between Jersey and } \\
\text { France (Normandy) }\end{array}$ & $\begin{array}{l}\text { Peacock (1865); } \\
\text { Sébillot (1899) }\end{array}$ \\
\hline 12 & $\begin{array}{l}\text { Brittany, France } \\
\text { (north coast) }\end{array}$ & $\begin{array}{l}\text { off the Lannion coast (Saint- } \\
\text { Michel-en-Grève; Sept-Îles; } \\
\text { Tréguier) }\end{array}$ & $\begin{array}{l}\text { The place(s) known as Lexobie and La } \\
\text { Ville des Sept-Îles disappeared }\end{array}$ & $\begin{array}{l}\text { Fréminville (1837); } \\
\text { Sébillot (1905: 52) }\end{array}$ \\
\hline 13 & $\begin{array}{l}\text { Brittany, France } \\
\text { (north coast) }\end{array}$ & off the coast at Plouguerneau & $\begin{array}{l}\text { The former town of Tolente is } \\
\text { submerged here }\end{array}$ & $\begin{array}{l}\text { Brousmiche (1891: } \\
\text { 33); Gould (1921: 128) }\end{array}$ \\
\hline 14 & $\begin{array}{l}\text { Brittany, France } \\
\text { (west coast) }\end{array}$ & Douarnenez Bay & $\begin{array}{l}\text { Likeliest location of submerged city of } \\
\text { Ys (Ker-Is), said to have been } \\
\text { submerged }\end{array}$ & $\begin{array}{l}\text { Guyot (1926); } \\
\text { Doan (1981) }\end{array}$ \\
\hline 15 & $\begin{array}{l}\text { Brittany, France } \\
\text { (southwest } \\
\text { coast) }\end{array}$ & off Concarneau, Finistère & $\begin{array}{l}\text { Île du Loc'h (and others in the Glénan } \\
\text { Islands) were once contiguous with } \\
\text { the mainland }\end{array}$ & $\begin{array}{l}\text { Reclus (1877: 601); } \\
\text { Sébillot (1905: 70) }\end{array}$ \\
\hline
\end{tabular}

Table 1. Stories of submerged lands referenced in the text.

Story 1 was first written down by Martin (1753) following his AD 1697 visit to the remote Hebridean island of St Kilda where he saw what he was told was the former dwelling (Taigh na Banaghaisgeich) of a female warrior about whom the islanders told many stories. One of note was that she was "much addicted to Hunting, and that in her Days all the Space betwixt this Isle and that of Harries [Harris Island], was one continued Tract of Dry Land ... 'Tis said of this Warrior, that she let loose her Grey-hounds after the Deer in St Kilda, making their Course towards the opposite Isles" (1753: 15). There is a comparable story from the Hebridean island of Harris, "a 
long and involved legend of a female warrior, who used to hunt over the dry land between the Long Island [Harris and Lewis] and St Kilda" (Maclean, 1972: 28); more specifically, "according to local tradition, land is said at one time to have linked St Kilda with the Long Island. Legends says that this formed the hunting-ground of a former Princess of Harris" (Jehu and Craig, 1926: 474). These stories may recall times when sea level was lower in this area and it was possible to move (largely) on foot between what are now islands.

Evidence for submergence of former land connections between (what are now) islands is found elsewhere in the Outer Hebrides. Early writers made much of their observations of submerged forests and peats; for example, off western Pabbay Island (North Uist) "where the sea ebbs out in spring tides to a great distance, there are visible, at the very lowest ebb, large trunks of trees; the roots of which, spread out widely and variously, are fixed in black moss, which might be dug for peat to a great depth" (Sinclair, 1794: vol 10, 373-4). In the 1930s, "an interesting and deeply grounded tradition among the people of Pabbay and Berneray [stated] that in former times the two islands were only separated by a very narrow channel, so that people could shout across and be heard, or even throw things across" what is today a 3.3-km ocean gap (Elton, 1938: 287). The same author notes that this tradition, which he collected from three independent sources, "may possibly be based on a real submergence within historical times" ( $p 288$ ). Recent archaeological work has uncovered submerged forest off the island of Benbecula, dating to 7900-3500 BP (Hardy et al., 2021).

Story 2 recalls a time when giants are said to have built a causeway between Northern Ireland (where the Giant's Causeway is) and the Isle of Staffa (Inner Hebrides) that enabled them to cross this part of the Irish Sea to reach the other's territory. The story is preserved within the Fionn Saga that recalls the exploits of Fionn mac Cumhaill (Finn McCool), hereafter Fionn, including his association with submerged lands, mostly in the northern part of the Irish Sea. The story goes that Fionn, in order to confront a rival giant (named Benandonner) in Scotland, started building a causeway (or a series of giant stepping stones) across the ocean, something he abandoned after he realised his rival was larger and more likely to defeat him in combat (Andrews, 1913: 90-91). Some versions of the story also recall the Scottish giant starting to build a causeway, perhaps from Staffa (Garnett, 1811: 231), by which he reached Ireland but was tricked to avoid a fight with Fionn and returned to Scotland, pulling up the flagstones of the causeway as he went: a possible recollection of submergence. The Isle of Man (shown in Figure 2B) is said to have been formed when Fionn scooped up earth from the hollow where Lough Neagh is found today to throw at the retreating Benandonner (Murphy, 1953). The stories about people crossing between Scotland and Ireland may have distant echoes in the time when sea level was low enough to enable this, perhaps with details about the columnar basalts so prominently displayed at the Giant's Causeway (Ireland) and Fingal's Cave (Staffa) being added later to rationalize historical observations. In addition, it should be noted that "the Gaelic tales abound in allusions to a beautiful country situated under the [Irish] sea-an enchanted land sunk at some remote time, and still held under spell. In some romantic writings it is called Tir-fa-tonn, the land beneath the wave" (Joyce, 1920: 462). 
The earliest folk traditions about King's Cave at Drumadoon on the Isle of Arran name it as the place where Fionn lived while he and his followers (féinne) hunted on Arran but also where a son was born to him. From Drumadoon, Fionn "formed a bridge of set of stepping-stones across to Kintyre" (Balfour, 1910: 252) on the Scottish mainland. An earlier account noted that the 'old people' of Arran "have many ridiculous stories about Fionn and his heroes, which have been transmitted, from a remote period, by father to son, and in their progress becoming more and more extravagant ... They say that Fionn made a bridge from Kintyre to this place [Drumadoon], over which he could pass, by a few steps, from one land to the other" (Headrick, 1807: 160). These stories may be an echo from a time when the two landmasses were joined above sea level. It has been argued (Nunn, 2018: 249-50) that in many cultures stories about giant beings originated when orally-transmitted memories of former dry-land connections between nearby landmasses (when sea level was lower) started to become less plausible in their re-telling requiring, as both Headrick (1807) and many others have inferred (Vansina, 1985, Barber and Barber, 2004), embellishment and exaggeration to ensure the stories continued to be told.

Story 3 tells that beneath the surface of Lough Gill adjoining the town of Sligo, there lies a 'fairy city' with "magnificent streets and buildings" (Wood-Martin, 1882: 379), something explainable by the once-widespread belief that "the original town of Sligo ... stood on a plain now overspread by the waters of Lough Gill, and that the islets studding the bosom of the lake are the crests of verdant knolls which formerly adorned its green expanse" (Wood-Martin, 1902: 220). To understand how this can be interpreted as a recollection of (relative) sea-level rise, it should be appreciated that Sligo is a coastal town, today occupying a barrier between Lough Gill and the Atlantic Ocean today.

Mermaids commonly feature in stories along the coast of County Sligo, suggesting that these may have evolved as land was gradually submerged here and memories of the associated people and places remained fresh in the minds of local residents. In comparable stories from across the world, memories of recently-sunken lands are kept alive through folk traditions that their inhabitants still live beneath the ocean surface (Nunn, 2021). Such a tradition refers to the submerged parts of former Sligo Town, where a boatman was once asked if he had ever seen any buildings beneath the waters; "'In troth, I have', was the ready answer, 'and shure, on a still summer's day, won't you see the smoke from the chimneys rising straight up in the air from the surface of the lake'" (Wood-Martin, 1902: 221). And some $80 \mathrm{~km}$ west of Sligo Town, there are stories about the ocean around Kid Island (County Mayo) that recall people living (as they did on the land) on the sea floor (Kingshill and Westwood, 2014: 416-7). Elsewhere in the world, for example at Solo Island (Kadavu, Fiji), local sailors on a calm day claim to be able to hear cocks crowing and mosquitoes buzzing on the submerged land of Lomanikoro (Nunn, 2021).

Comparable inferences can be drawn from the disproportionate number of 'sightings' of the legendary (and unattainable) island named Hy Brasil off the coast of this part of Ireland (WoodMartin, 1902, Westropp, 1912-1913), discussed below.

Story 4 recalls the presence of the island of Kilstuithin, "an enchanted fort under the sea in Liscannor Bay" that, in a story from the year 1750, periodically becomes visible "surrounded by 
a wall of water" (Westropp, 1908: 198). Stories about Kilstuithin and Hy Brasil periodically reappearing (Westropp, 1912-1913, Babcock, 1922) are found in many other parts of the world; an example is those of the Fiji island of Burotukula (Geraghty, 1993, Nunn, 2009). More recentlycollected traditions tell of how Kilstuithin was either once home to a cattle thief who, in a scuffle, lost the 'key' to the island which sank beneath the waves or, more prosaically, to the island's king who dropped the key in battle. Westropp recalls how he heard 'a pretty tale' in the area in 1878 about how "boatmen at times smelt the wild thyme of the flowery fields" ( $p$ 199) of the submerged island as they rowed over the place where it lay, going on to ask whether it is "too daring to conjecture that [this story] rests on a firm historic basis?" (p 199). Part of the reason for this was his observation that "the whole coast [of the west coast of Ireland] gives many traces of submergence during untold ages" and that "our legends are full of it" (pp 199-200), the former supported by more recent interpretations of submerged forests and peat bogs in this region as a result of sea-level rise over several millennia (Jordan et al., 2017).

Story 5 refers to an island, now largely submerged, in Ballyheigue Bay that "at a remote period was overflowed in one of the encroachments which the Atlantic has made on that part of the coast of Kerry ... fishermen declare they have often seen the ruined walls of an old chapel beneath them in the water" (Croker, 1844: 139). One story holds that when any member of the Cantillons, the local squirearchy, died, their body would be placed on the shore and carried by their spirit ancestors to the island for burial. But one day, breaking protocol, a man sought to witness this, so the island was sunk as punishment (pp 139-143).

A variant on this story is that one of the Cantillons once married a 'sea-princess' who died young and was buried on the island, her grieving father ordering the waves to 'cut its roots' and submerge it "beneath the grey and endless deep" (Westropp, 1912-1913: 249-250). The story can be readily interpreted as a memory of the former encroachment of the sea across the land. Comparable stories come from islands in Solomon Islands and Vanuatu where vengeful parents/spouses cause entire islands to disappear because of the reprehensible behaviour of persons with whom they were associated (Nunn, 2009).

Story 6 recalls a time when the Point of Ayre on the Isle of Man (central Irish Sea) was contiguous with the Mull of Galloway on the Scottish mainland $40 \mathrm{~km}$ away (Welch, 1836). Around the Isle of Man, there are also many traditions about submerged islands. From one of these, remains of ruined buildings were occasionally brought up in fishing nets (Gill, 1932). Similar stories have long been used to reinforce stories about Lyonesse (Story 10 ), including the $18^{\text {th }}$-century account that recalled how fishermen, "casting their hooks thereabouts, have drawn up pieces of doors and windows" (Carew, 1723: 3) in the area between Cornwall and the Scilly Isles.

Manx traditions also mention the existence of a sunken land off the island's coast where "sailors assert that they frequently hear cattle lowing, dogs barking, beneath the waves" (Bassett, 1892: 481). It is plausible that such memories represent echoes of a once much larger body of stories recalling when sea level was lower around the Isle of Man. 
Story 7 refers to the submerged land known as Tyno Helig (Helig's Vale) lying off the Conway coast. Some accounts explain the story by records of a 'great inundation' here about AD 634 when the area was ruled by (Lord) Helig ap Glannawg who had angered the 'sea folk' and was punished in consequence (Curran, 2000). Through the sea-floor Lavan ('weeping') Sands that cover the area now, were apparently once visible the ruins of houses and a causeway, dismissed by writers like North (1957) as 'illusory', glacial outwash structures easily mistaken as artificial constructions.

In his careful and methodical investigation of stories about 'sunken cities' off the coast of Wales, North (1957) recognizes that traditions about Tyno Helig (Llys Helig) are ancient and have been adapted through time but concludes that they were inspired by catastrophic inundations. While this conclusion was prescient because it treats what others dismissed as 'legend' or 'myth' as being empirically based, it is important to appreciate that North was writing before it was widely known that sea level had fluctuated in the past so he had no other option except to invoke catastrophe to explain submergence. Today it is unclear why such an inundation, presumably a tsunami or storm surge, would have resulted in permanent submergence of the coast here. As elsewhere, this probably represents an attempt at rationalizing the evidence and memories of submergence in a time before there was any understanding that the ocean surface had itself changed significantly in the past (Nunn, 2018).

Story $\mathbf{8}$ is that of the submerged lands in Caernarvon Bay centred around Caer (Castle) Arianrhod, marked today by a reef of stones but mostly beneath six metres or so of ocean. A range of traditions has been recorded, especially in the comprehensive collection of Welsh stories from the $12^{\text {th }}$ and $13^{\text {th }}$ centuries known as the Mabinogian (Jones and Jones, 2001). Several mention how Caer Arianrhod was once contiguous with the mainland and how its human-made features can be seen below the ocean surface. But what is different from similar stories (like 7 and 9) is the absence of any mention of catastrophic inundation, Caer Arianrhod being a land "destroyed by erosion and subsidence" (North, 1957: 223). The same authority concludes that stone structures and arrangements claimed to be part of Caer Arianrhod are in fact natural (glacial) formations.

Story 9 is that about Cantre'r Gwaelod, the land of the Lowland Hundred which included the eponymous city (and perhaps fifteen others), that became submerged somewhere in Cardigan Bay. The most common narrative detail is that the city of Cantre'r Gwaelod was the seat of King Gwyddno who ruled the surrounding countryside (Maes Gwyddno). Yet the city was one that had been threatened by the ocean for a long time and had, in consequence, a series of tidal (sluice) gates that were closed at high tide to prevent the city being flooded. One night, the king's drunken steward Seithennin failed to close the flood gates so the city was inundated and abandoned, a similar narrative to that of Story 14 (below). The similarities in these two stories may come from their fusion in the mind and reports of Breton scholar Hersart de la Villemarqué, who in 1838-1839 was explicitly charged by the French Government to visit Wales 'pour étudier la langue et la literature galloise' ('to study Welsh language and literature') (Nunn, 2020). 
There are numerous detailed stories about Cantre'r Gwaelod that specify its extent, approximate location, and links to various culture heroes (North, 1957). Yet no tangible evidence of its existence has been uncovered, leading some to insist it is an enduring fictional cultural narrative (Kavanagh and Bates, 2019). Others disagree, highlighting the probable origin of such stories as lying in people's observations of changes in coastline position (North, 1957, Nunn, 2018, Nunn, 2020), stories sustained and periodically rejuvenated by the actions of new sets of culture heroes (Bromwich, 1950). Yet most authorities agree that the allegedly human-made structures - long stone 'walls' named sarns - are (as for stories 7 and 8) mere products of glacial outwash and not the 'evidence' for Cantre'r Gwaelod that some claim them to be.

Story $\mathbf{1 0}$ is that of the 'lost land' of Lyonesse, generally placed either off the coast of Cornwall (usually west of Land's End) or within the Scilly Isles archipelago. While commonly linked to a catastrophic flooding of the area, something supported by accounts of such events like that on $3^{\text {rd }}$ November 1099 when "the sea overflowed the shore, destroying towns, and drowning many persons, and innumerable oxen and sheep" (Forester, 1854: 206), these could not have resulted in permanent submergence. Mainly for this reason, a few influential scholars have favoured the idea that Lyonesse stories recall the gradual postglacial flooding of the Scilly Isles platform (Borlase, 1756, Crawford, 1927), something made more plausible by the discovery that people were living on these islands at the time when the main ones were still connected (Figure 3) and witnessed its progressive dismemberment as sea level rose subsequently (Charman et al., 2016, Barnett et al., 2020).

Story 11 refers to a group of stories that recall times in the past when it was possible to walk from (what are now) the Channel Islands to the adjacent French mainland (Peacock, 1865, Sébillot, 1899). One account states that "in past times, the [English] Channel was not as broad as it is now; one could go to Jersey [from mainland France] without encountering any obstacle other than a stream which was not very wide"; in the original, "au temps jadis la Manche n'était pas si grande que maintenant; I'on pouvait aller à Jersey sans rencontrer d'autre obstacle qu'un ruisseau qui n'était pas tres large" (Sébillot, 1899: 23).

Another account references French stories that recall a time before the English Channel (La Manche) formed, noting that a Roman road once connected Coutances (Normandy) to Jersey and that 'the last decisive assault' on the French coast occurred in AD 709 (Hugo, 1866); "A Roman road, still visible, led from Coutances to Jersey. It was in 709 ... that the ocean tore Jersey from France. Twelve parishes were swallowed up"; "Une voie romaine, encore visible, menait de Coutances à Jersey. C'est en 709, nous l'avons dit, que l'océan a arraché Jersey à La France. Douze paroisses furent englouties" (Hugo, 1866: 28). 


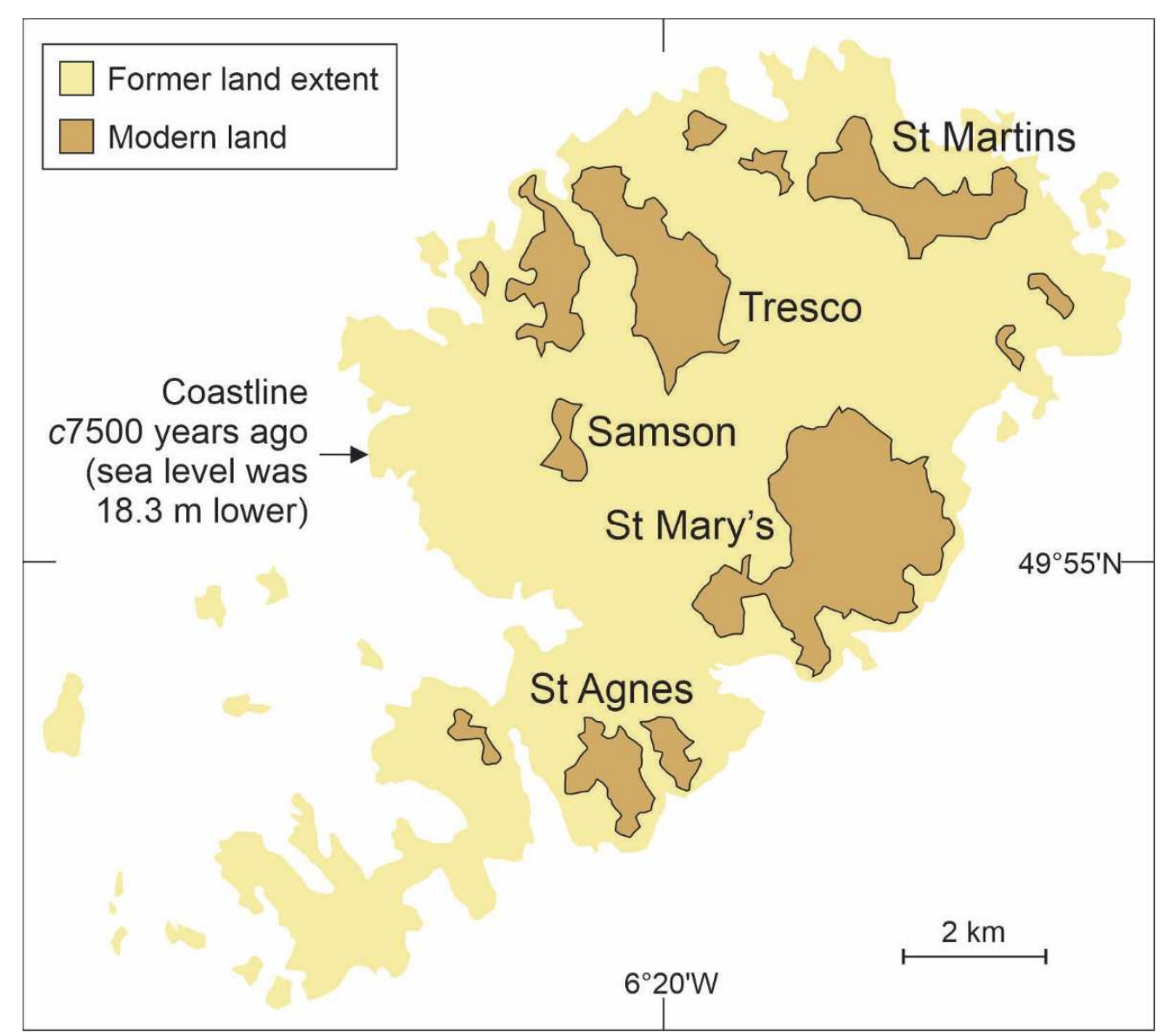

Figure 3. Around 7500 years BP (sea level $18.3 \mathrm{~m}$ lower), the Scilly Isles were occupied by people; Mesolithic occupation was c 10,500-6000 years BP (Charman et al., 2016). It is possible that Lyonesse stories originated in the Scilly Isles around this time, not least given the antiquity proposed for similar stories elsewhere (Nunn, 2018).

A redrawn map showing what may be the late Roman period coastline in this area, possibly as rendered in oral traditions of the time around $A D$ 350-400, is shown in Figure 4 . This is a redrawing of the 1714 Deschamps-Vadeville map found in tatters, "trouée par les vers et I'humidité" (Chèvremont, 1882: 370) ('eaten by worms and damp'), at Mont St-Michel. While a possible forgery (see Eigen, 2018: 162-165), this map has also been proposed as being an authentic reproduction of a late Roman period map (Rodwell, 1996, Cracknell, 2005). 


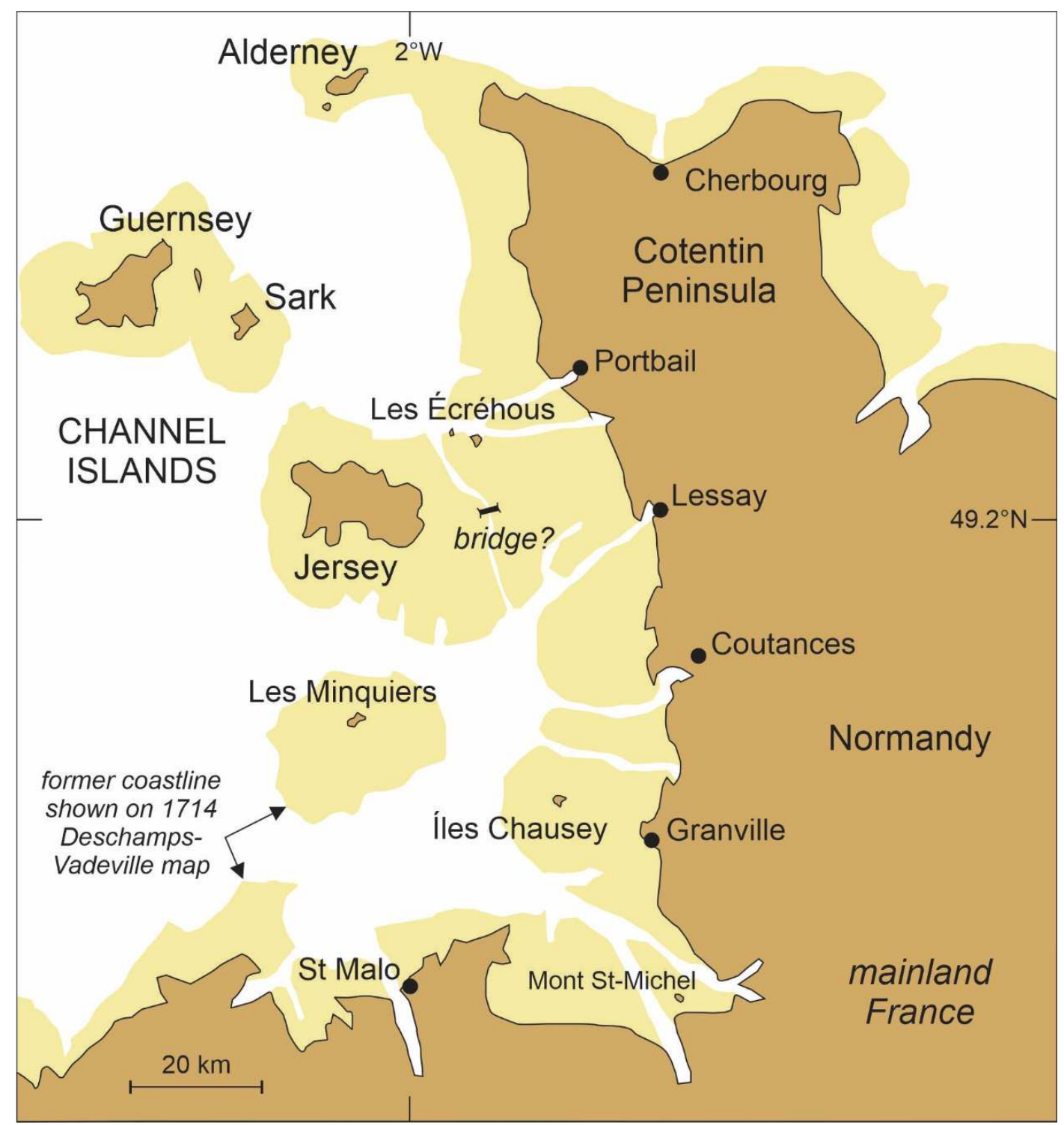

Figure 4. The Channel Islands and adjacent parts of France showing the former coastline as represented in the 1714 Deschamps-Vadeville map (Chèvremont, 1882). It is possible that this map was copied from a Roman map that used oral memories to reconstruct an earlier coastline. Corroborative details may be preserved in traditions like that which recalled when Jersey residents might walk to (what is now) mainland France utilizing a bridge at one point.

Most stories here refer to the island of Jersey (Poingdestre, 1889) and marry traditions of land loss with observations of submerged forests; "A tradition has been handed down, in Normandy, that there existed formerly, between Jersey and the diocese of Coutances, a forest, which extended from Le Mont St. Michel to Cherbourg : it is conjectured that the greater part of this forest has been absorbed by the sea; because, at spring-tides, a number of trees and stumps are discovered" (Plees, 1817: 12). 
One story mentioned by Poingdestre, writing in 1682, was a "fabulous Tale of the conjunction of Jersey to Normandy" ( $p$ 75) that recalled when it was possible to walk from Jersey to Normandy, crossing the only prominent river by a bridge and "paying a small toll to the Abbey of Coutances" (Plees, 1817: 9). While this story has been dated by approximate history to the year AD 565, which explains why some judge it apocryphal (Kavanagh and Bates, 2019), the error is treating such estimates, derived before modern scientific reconstructions of past sea-level changes, as unchallengeable. Comparable stories of coastal submergence, albeit more fragmented, are known from other islands in this group (Tupper, 1854: 28). In Australian stories, there are many parallel situations; for example, the Lardil people of the Wellesley Islands (Gulf of Carpentaria, northern Queensland) recall how "in the beginning, our home islands ... were not islands at all, but part of a peninsula running out from the mainland" (Roughsey, 1971: 20).

Story 12 comes from the north coast of Brittany and refers to a submerged land (and/or town) known as Lexobie (or La Ville des Sept-îles or Triagoz), although it is unclear whether these refer to the same place or to one or more of the many other stories of submerged lands further east in the Gulf of St Malo (Manet, 1839). One of the earliest written accounts spoke of Lexobie being off the coast of Saint-Michel-en-Grève or perhaps further east off Tréguier; it was "one of the great and ancient cities, of which the old Breton traditions speak so often, and which are today entirely erased from the surface of the earth"; in the original, "une de ces grandes et antiques cités, dont parlent si souvent les vieilles traditions bretonnes, et qui sont aujourd'hui entièrement effacées de la surface du sol" (Fréminville, 1834: 17).

In some accounts, La Ville des Sept-îles was a huge land, even stretching to the west coast of Brittany, but more often it is confined to the seven islands off the Renote (Trégastel) Peninsula (Sébillot, 1899, Sébillot, 1905) where a comparable history to that proposed for the Scilly Isles (see Figure 3) may explain stories of land submergence here.

Story 13 refers to the story of the former city of Tolente, capital of the now-submerged land of Ach (Aginense) off the Brittany coast near Plouguerneau (Le Grand, 1659). Possibly the same place as (or more likely, close to) the Gallo-Roman port of Gesocribate, Tolente is said to have been submerged during a 'great subsidence', a "grand affaissement", during the $7^{\text {th }}$ century AD (Kervran, 1977: 82). Others also infer the submergence of Tolente occurred around the same time (Brousmiche, 1891, Vallaux, 1903) although the long-term (Quaternary) tectonic stability of this area suggests abrupt change of this kind is unlikely to have occurred (Raimbault et al., 2018) and that the tale of Tolente is only the latest expression of an older story recalling the long-term submergence of this coastline.

Story 14 is that of the city of Ys (Ker-ls) that is perhaps the best-known of all the Breton stories of submerged lands (Guyot, 1926). Ys is commonly located in the Baie de Douarnenez although no trace of it has been found here and other locations are possible (Spence, 1917: 184). The most common story is that Ys was the seat of King Gradlon whose daughter (like the drunken Seithennin - see Story 9) was persuaded to open the flood gates at high tide, inundating the city and forcing its abandonment (Doan, 1981). Gradlon remains a prominent part of history in this part of Brittany, and stories of Ys have been kept alive by former traditions of holding church 
services above the submerged city, the remains of which when the sea is calm "may be clearly seen at the bottom of the bay" (Anonymous, 1872: 73).

Like traditions about Cantre'r Gwaelod (Story 9) and similar, it seems likely that Ys had been accommodating the effects of a rising sea level for some time, so the overwhelming of its sea defences was inevitable (Nunn, 2018, Nunn, 2020). As with the submerged Breton 'cities' of Lexobie (Story 12) and Tolente (Story 13), it is plausible to suppose that Ys was a walled/protected settlement that lay on the coast at some point in the distant past but was overwhelmed by the rising ocean, recollections of its existence and associations passing slowly from fact to (exaggerated/narrativized) memory to myth. Sea defences of this kind have a long history; a submerged seawall off the Carmel coast of Israel was built between 7000 and 7500 BP (Galili et al., 2019).

Story 15 refers to islands (notably île du Loc'h) in the Glénan Archipelago off the south coast of Finistère, recalling a time when these were contiguous with the mainland. For example, geographer Elisée Reclus noted that "west of the Quiberon peninsula, other detached lands, the island of Groix and the Glénan archipelago continue the old coast. The traditions even state that the nine islets of Glénan were once a sizeable island: their destruction by the waves of the sea is a geological process that the people living there at the time would have witnessed"; in the original, "À l'ouest de la presqu'île de Quiberon, d'autres terres détachées, l'île de Groix et l'archipel des Glénan, continuent l'ancienne côte. Les traditions racontent même que les neuf îlots des Glénan étaient jadis une île considerable: leur destruction par les flots de la mer est une oeuvre géologique à laquelle les indigènes auraient assisté" (Reclus, 1877: 601).

More detail of these traditions was given by Paul Sébillot;

"The memory of the time when this archipelago was joined to the continent has not been forgotten yet: on the coast of Fouesnant they say it was once possible to travel on foot from Becmeil [mainland] to île aux Moutons, today a great distance out to sea; the tip of Trévignon touched the island of Stork, and every spring a procession leaving the church of Loctudy [mainland] went to one of the islands, following an alley of large trees. It is said in Carnac that in the past there was only a horse jump between Île de Houat and Pointe de Quiberon, now separated by eight kilometres of salt water". In the original, "Le souvenir du temps où cet archipel tenait au continent n'est pas encore effacé : sur la côte de Fouesnant on dit qu'on allait autrefois à pied de Becmeil à l'île aux Moutons, aujourd'hui à une grande lieue en mer; la pointe de Trévignon touchait à l'île de la Cigogne, et à chaque printemps une procession sortie de l'église de Loctudy se rendait à l'une des îles, en suivant une allée de grands arbres '. On raconte à Carnac que jadis il n'y avait qu'un saut de cheval entre l'île de Houat et la pointe de Quiberon, séparées maintenant par huit kilomètres d'eau salée" (Sébillot, 1905: 70). 
Like stories from Jersey (Story 11) and many others discussed above, this story is a plausible memory of a time when the sea level here was lower and what are today offshore islands were part of the mainland.

\section{DETERMINING MINIMUM AGES FOR SUBMERGENCE STORIES}

For comparable 'submergence stories' from the margins of Australia, minimum ages were determined by identifying the depth (below present sea level) of the shallowest shoreline to which a particular story (or group of stories) refers, then using reconstructions of postglacial sealevel history to assign an age (range) to that shoreline and a minimum age to the associated story (Nunn, 2016, Nunn and Reid, 2016). While there are many possible sources of error in this process that make story ages only approximations, it nevertheless provides cogent estimates of narrative/memory longevity that, by comparison with more precisely determined age estimates for some other ancient stories, appear plausible. More recent efforts to extend this model to other natural phenomena, especially volcanism (Nunn et al., 2019, Wilkie et al., 2020) and even to 'submergence stories' outside Australia (Nunn, 2018), suggest that its application to the robust data set outlined in Section 3 (summarized in Table 1) will yield unique insights.

In Table 2, the minimum (shallowest) depth of the coastline (relative to today) for which each of the 15 stories would be true is given (Column 4). Depths are derived from bathymetric charts for each study site and, while these are the closest approximations available, they also contain localized sources of potential error. For instance, modern sea-floor depths are unlikely to be exactly those which existed thousands of years ago, not least because sediment has accumulated on them (making them shallower), something that would be commonest in nearshore or bayhead settings; examples might include Stories \#3, \#13 and \#14. Conversely, it is possible that in some more open settings, especially those incorporating steep undersea slopes, that depths increased over the past few millennia for a range of reasons from scouring to collapse. The latter may be an explanation for the 110-m depth, an outlier in the data set (Table 2), calculated for Story \#1 that recalls when the area between St Kilda and Harris islands was dry land. Either a flank landslide or a collapse (tectonic or gravity-driven) of what is now the saddle east of St Kilda could have created this deep area subsequent to its submergence, a possibility strengthened by the well-known association between past periods of sea-level rise and catastrophic collapses of steep-sided continental shelves caused by the dissociation of methane hydrates (Sultan et al., 2004).

The history of postglacial sea-level change varies within the study region (Figure 5) meaning that, unlike far-field tectonically-stable postglacial Australia, site-specific sea-level curves are needed to obtain accurate ages to each former (undersea) shoreline. For sites in the British Isles, this study used sea-level curves based on the GIA models of Bradley et al. (2011) and Kuchar et al. (2012), compared in Shennan et al. (2018). While these models show the best fit (prediction versus sea-level index data) for the British Isles, the fit is less for Brittany so the ICE 6G GIA model, which fits better here, is used (Peltier et al., 2015). Using the Bradley, Kuchar and ICE 6G curves, minimum ages are assigned to each group of stories (Column 6 in Table 2). Again, given the degree of spatial variability of postglacial isostatic adjustment and the impossibility in some 
instances of identifying a sea-level curve for the precise site of the story, there may be compounding errors in the estimated ages.

\begin{tabular}{|c|c|c|c|c|c|}
\hline $\begin{array}{l}\text { Number on } \\
\text { Figure } 2 B \\
\text { map }\end{array}$ & Area & $\begin{array}{l}\text { Minimum depth } \\
(\mathrm{m}) \text { below } \\
\text { present mean } \\
\text { sea level }\end{array}$ & $\begin{array}{l}\text { Applicable } \\
\text { sea-level curve } \\
\text { (in Figure 5) }\end{array}$ & $\begin{array}{c}\text { Minimum age range in } \\
\text { years BP (derived from } \\
\text { Figure 5) }\end{array}$ & Source/s of age data \\
\hline 1 & $\begin{array}{l}\text { Outer Hebrides, } \\
\text { Scotland }\end{array}$ & $110(35-40)^{1}$ & Bradley/Kuchar & $\begin{array}{c}\text { uncertain }(14,345- \\
15,000)\end{array}$ & Figure 5a, Area 1 \\
\hline \multirow{2}{*}{2} & \multirow{2}{*}{$\begin{array}{l}\text { Irish Sea } \\
\text { (northern part) }\end{array}$} & $(6-15)^{1}$ & \multirow{2}{*}{ Bradley/Kuchar } & $(10,670-11,170)$ & Figure 5a, Area 2a \\
\hline & & $(4-15)^{1}$ & & $(10,300-10,800)$ & Figure $5 \mathrm{a}$, Area $2 \mathrm{~b}$ \\
\hline 3 & $\begin{array}{l}\text { Co. Mayo, } \\
\text { Ireland }\end{array}$ & $4-6$ & Bradley/Kuchar & $6010-6510$ & Figure 5a, Area 3 \\
\hline 4 & $\begin{array}{l}\text { Co. Clare, } \\
\text { Ireland }\end{array}$ & $15-30$ & Bradley/Kuchar & $7830-10,000$ & Figure 5a, Area 4 \\
\hline 5 & $\begin{array}{l}\text { Co. Kerry, } \\
\text { Ireland }\end{array}$ & $7-15$ & Bradley/Kuchar & $5000-7450$ & Figure 5a, Area 5 \\
\hline 6 & Isle of Man & $10-15$ & Bradley/Kuchar & $10,160-11,705$ & Figure 5a, Area 6 \\
\hline 7 & $\begin{array}{l}\text { Conway } \\
\text { (Conwy), north } \\
\text { Wales }\end{array}$ & \multirow[t]{2}{*}{$5-20$} & \multirow[t]{2}{*}{ Bradley/Kuchar } & \multirow[t]{2}{*}{$7505-10,455$} & \multirow[t]{2}{*}{ Figure $5 a$, Areas 7-8 } \\
\hline 8 & $\begin{array}{l}\text { Gwynedd, north } \\
\text { Wales }\end{array}$ & & & & \\
\hline 9 & $\begin{array}{l}\text { Ceredigion, west } \\
\text { Wales }\end{array}$ & $10-20$ & Bradley/Kuchar & $7805-9505$ & Figure 5b, Area 9 \\
\hline 10 & $\begin{array}{l}\text { Cornwall/Scilly } \\
\text { Isles, Southwest } \\
\text { England }\end{array}$ & $8-20$ & Bradley/Kuchar & $5485-7860$ & Figure $5 \mathrm{~b}$, Area 10 \\
\hline 11 & Channel Islands & $10-12$ & ICE-6G & $8020-8655$ & Figure 5b, Area 11 \\
\hline 12 & $\begin{array}{l}\text { Brittany, France } \\
\text { (north coast) }\end{array}$ & $10-20$ & ICE-6G & $7165-9300$ & Figure $5 \mathrm{~b}$, Area 12 \\
\hline 13 & $\begin{array}{l}\text { Brittany, France } \\
\text { (north coast) }\end{array}$ & $2-10$ & ICE-6G & $6100-7450$ & Figure 5b, Area 13 \\
\hline 14 & $\begin{array}{l}\text { Brittany, France } \\
\text { (west coast) }\end{array}$ & $15-30$ & ICE-6G & $8390-10,725$ & Figure 5b, Area 14 \\
\hline 15 & $\begin{array}{l}\text { Brittany, France } \\
\text { (southwest coast) }\end{array}$ & $20-25$ & ICE-6G & $10,000-10,865$ & Figure 5b, Area 15 \\
\hline
\end{tabular}

\footnotetext{
${ }^{1}$ the figures in brackets assume the story refers to an incomplete land connection
}

Table 2. Minimum depths/ages of shorelines to which stories plausibly refer. 

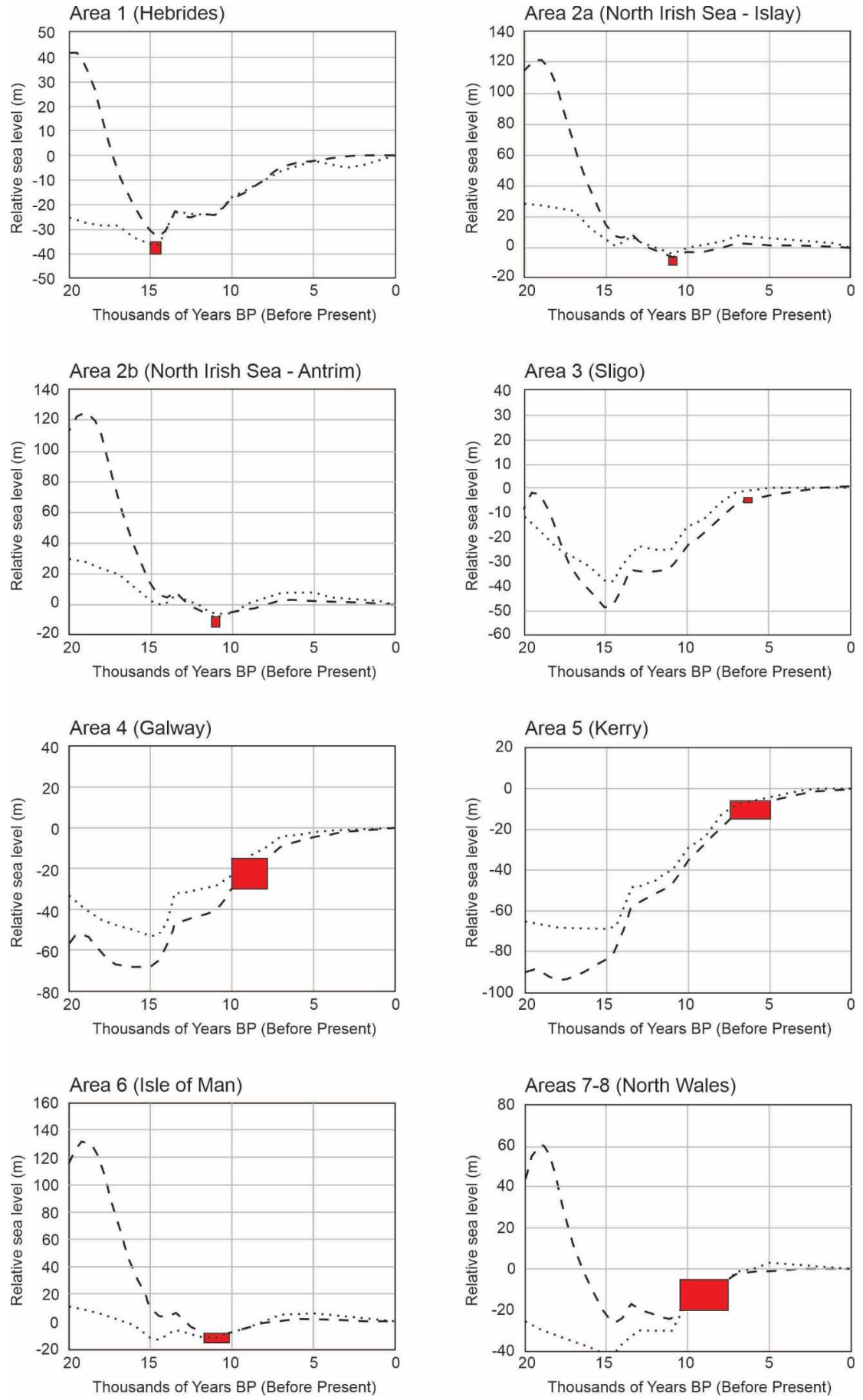

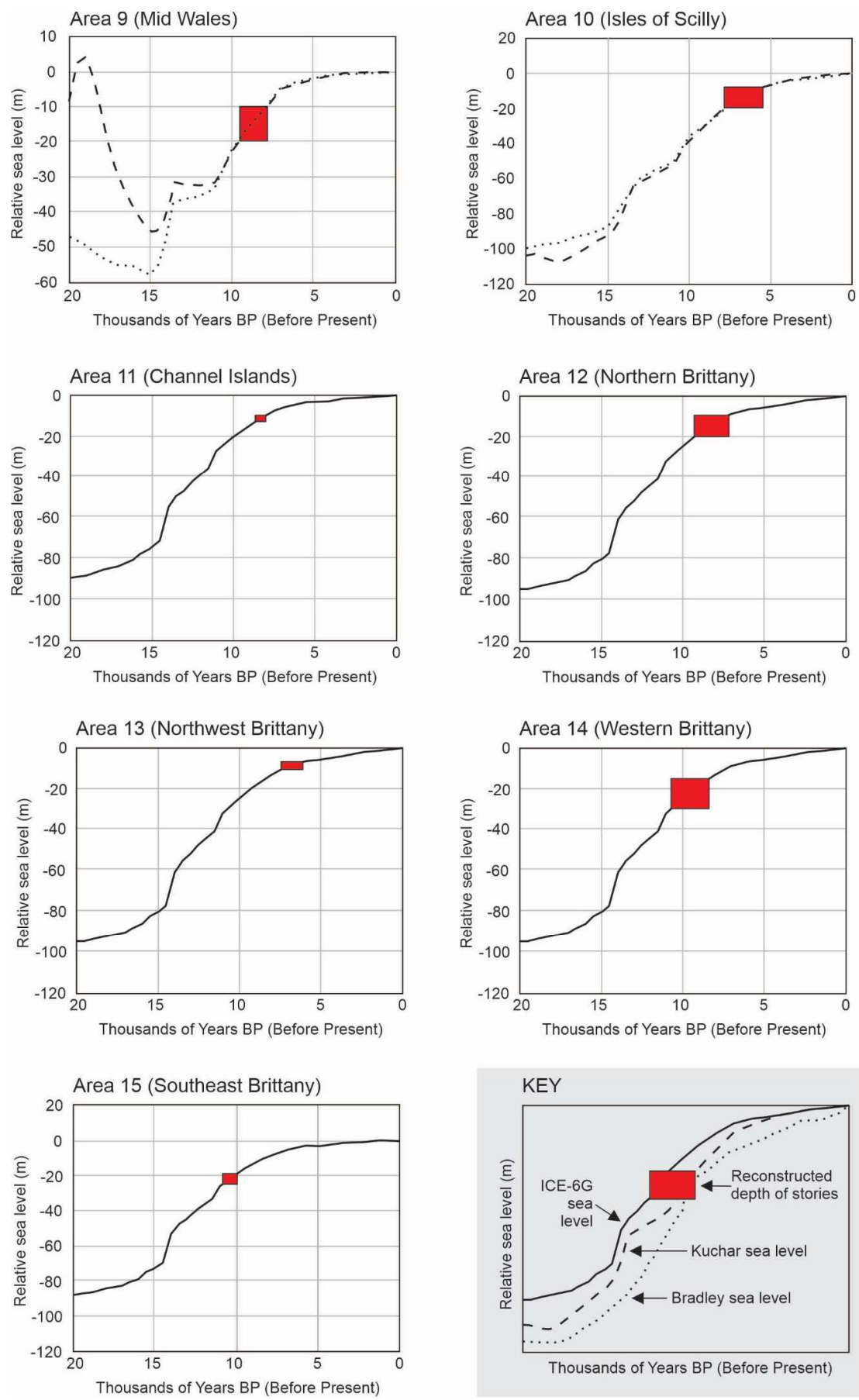

Figure 5 (in two parts). Relative sea-level changes within the past 20,000 years at selected sites within the study region. The Bradley and Kuchar models (Shennan et al., 2018) are considered to be best suited to the British Isles and the ICE-6G data (Peltier et al., 2015) better aligned with Brittany. Shaded (red) boxes represent the estimated depths of coastlines reconstructed from the 15 stories (Table 1). These graphs are used to assign minimum age ranges to these stories (listed in Table 2) and compared to Australian data in Figure 6. Note that the shaded boxes for Areas $2 a, 2 b$ and 3 have been assigned an arbitrary 500-year range in the absence of depthrange data. 
Notwithstanding potential sources of error, it is considered that the data in Table 2 represent plausible depth and age minima for each group of the 15 'submergence stories'. Most stories are considered as recalling past times when the shoreline was 5-20 m lower than it is today. People were demonstrably living in all these places at this time of lower sea level and it seems reasonable to suppose that they observed its rise and the effects this had on coastal landscapes and coastal societies. People's memories of submergence - likely in many instances to have proved both disruptive and traumatising - became readily incorporated into oral stories about the past, ascribed to the actions of the 'gods' in which the people believed, and often explained by divine punishment of human transgressions (Purzycki et al., 2016). By analogy with the Australian situation (Nunn and Reid, 2016, Porr, 2018), it is likely that the stories were kept alive both as part of a proscribed 'law', required to be learned by each new generation, and through cultural performance (storytelling, singing, dramatism, material creation).

Table 2 shows that all stories analysed appear to have endured for five thousand years or more, around half of them for more than seven thousand years. It is worth emphasising a common criticism of such age estimates, namely that representing the innate difficulties which many literate people have in believing that pre-literate (oral) societies could have passed such knowledge across several hundred generations in intelligible form. An appropriate response to this is that the events occurred, there is no doubt people witnessed the events being recalled, so the only real 'sticking point' is an individual's opinion about the capacity of oral societies to keep these memories alive for so long. Recent research has explored the range of efficacious techniques of memory recollection used in such contexts (Kelly, 2015, Kelly, 2016) while other research has shown beyond any doubt that memories of events which occurred more than five thousand years ago remain extant among traditional peoples in many parts of the world (Nunn, 2018, Nunn et al., 2019).

A handful of stories analysed may refer to events that occurred more than ten millennia ago (Table 2). While this may be close to 'the edge of memory', there has been a number of studies suggesting that in optimal circumstances, memories can be preserved this long; for example, a recent study of Budj Bim volcano in Australia suggested that Gunditjmara traditions recalling its youngest activity could have endured for around 37,000 years (Matchan et al., 2020). Stories of extinct animals, especially iconic megafauna, that appear to have endured for a similar length of time, could be explained by the periodic rejuvenation of memories of now-disappeared creatures by their transference to new creatures that in turn disappeared. This could also explain the possibility that the 'wildmen stories' of the people of Flores Island (Indonesia) may have originated at the time the last Homo floresiensis disappeared there, perhaps as much as 60,000 years ago (Forth, 2005).

\section{DISCUSSION}

This study has shown that there are at least 15 persistent groups of stories in northwest Europe that plausibly recall times when the ocean surface (sea level) was lower and how it subsequently 
rose across the land, inundating it permanently, with enduring consequences for the peoples occupying it. As with the body of equivalent Australian stories (Nunn and Reid, 2016, Nunn, 2018), the European stories vary from those that recall when places which are now islands were once contiguous with larger (continental) landmasses (e.g. Stories 1, 2, 6, 11, 15) to those that state there was once an extensive landmass, occupied by people, which lay offshore in an area now partly covered by ocean (e.g. Stories 7-10, 14). All the European stories, just as with the Australian stories, are clearly not 'flood stories' for the water that rises across the land never recedes subsequently. All these details make the 15 European stories (and probably many others, more fragmented, recently lost, from the same region) plausible recollections of postglacial sea-level rise.

By comparing Figs $2 \mathrm{~A}$ and $2 \mathrm{~B}$, it is possible to see that almost all 15 stories come from places where submergence has dominated in postglacial times. This is consistent with the notion that these stories genuinely recall land submergence. If these stories did not - if they were solely cultural inventions, for example - then you would expect their distribution to be more even. In this sense, it is interesting to note that stories proliferate along the coasts where land has been submerged recently; for example, there are no stories from the England-Scotland mainland north of the zero isobase in Figure 2A, whereas just to the south of this, stories are found in Wales (79) and the west of Ireland (3-5).

In places where emergence attributable to isostatic rebound has dominated, no/few stories are found. For instance, no stories are found along the coasts of mainland Scotland, which was mostly ice-covered until 15,000 years BP and has been rising ever since (Ballantyne and Small, 2019). The St Kilda-Harris story (\#1) is on the margins of the uplift area, close to the zero isobase in Figure 2A, making it more likely than not that this is a genuine recollection of submergence. The fact that there are no stories from anywhere along the mainland coasts of Scotland and northern England strongly suggests that submergence was never witnessed here, so it was never encoded into local traditions. The absence of such stories in these areas thus strengthens the argument for treating the presence of such stories elsewhere in the region as genuine recollections of land submergence.

Figure 6 shows that the European story dataset $(n=15)$ is comparable in terms of submergence depths and minimum ages to the dataset for Australian stories $(n=20)$; raw data are in SI1. The correlations between age and depth (Figure 6A, B) are of interest for they reflect the coherence of sea-level history in the two regions. Thus, around Australia, where postglacial sea-level change was effectively uniform, the correlation coefficient is 0.99 , whereas along the studied coasts in Europe, this was a more spatially variable phenomenon, explaining why the correlation coefficient is 0.86 .

The histogram (Figure 6C) shows the story minimum-age distributions. It is clear that the Australian stories are more tightly constrained, largely because sea level reached its present level here about 7000 years ago so all submergence stories are at least this old. In contrast, the European stories are more widely and unevenly distributed through time, in part because sea level has continued rising since the end of the LGM here. Other causes of the contrast may 
include sampling and issues affecting the preservation of stories, but maybe also the greater degree to which cultures in Europe could retain these, largely through mythologization, which appears less common in Australian Aboriginal cultures (Berndt and Berndt, 1994).
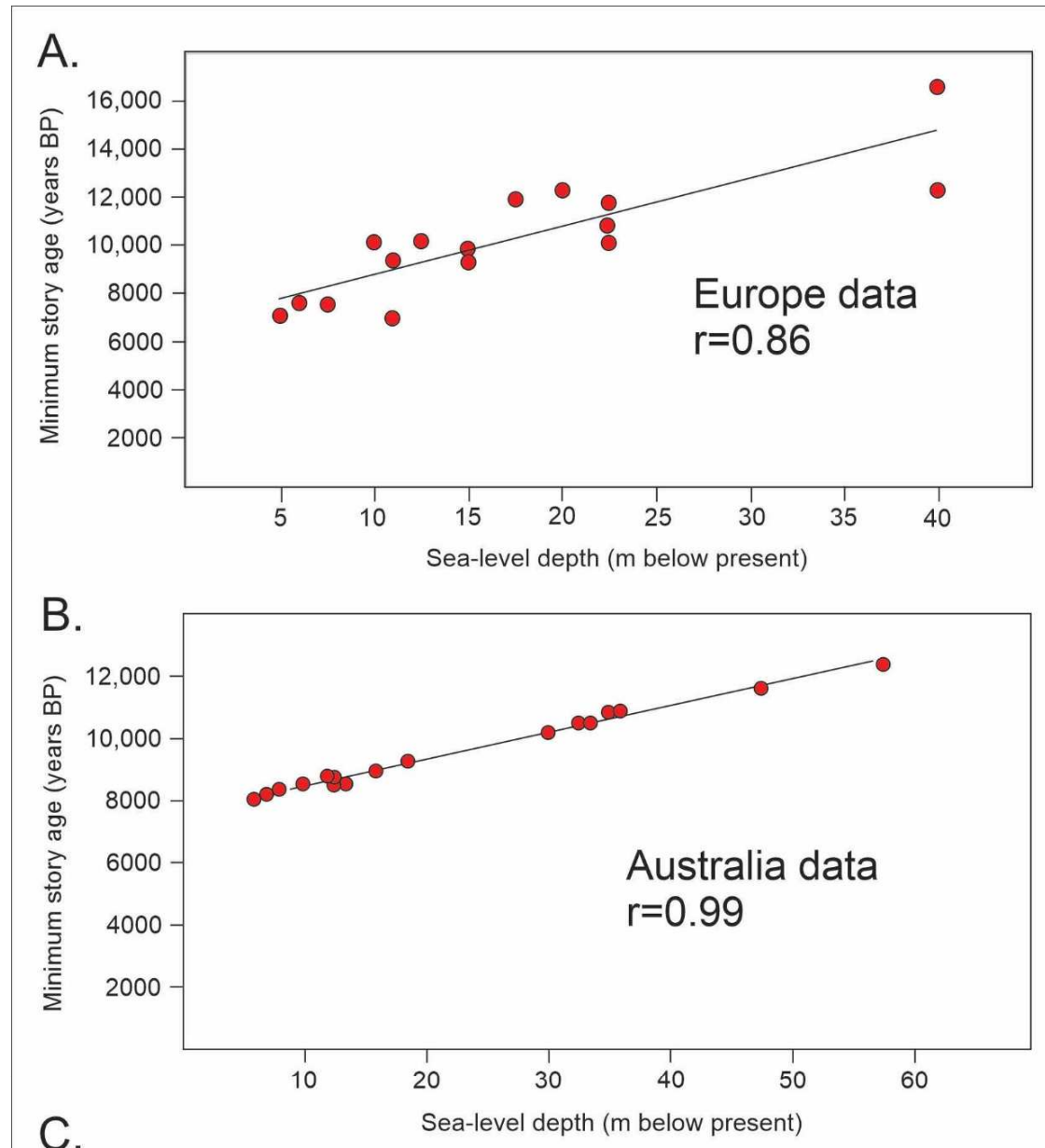

C.

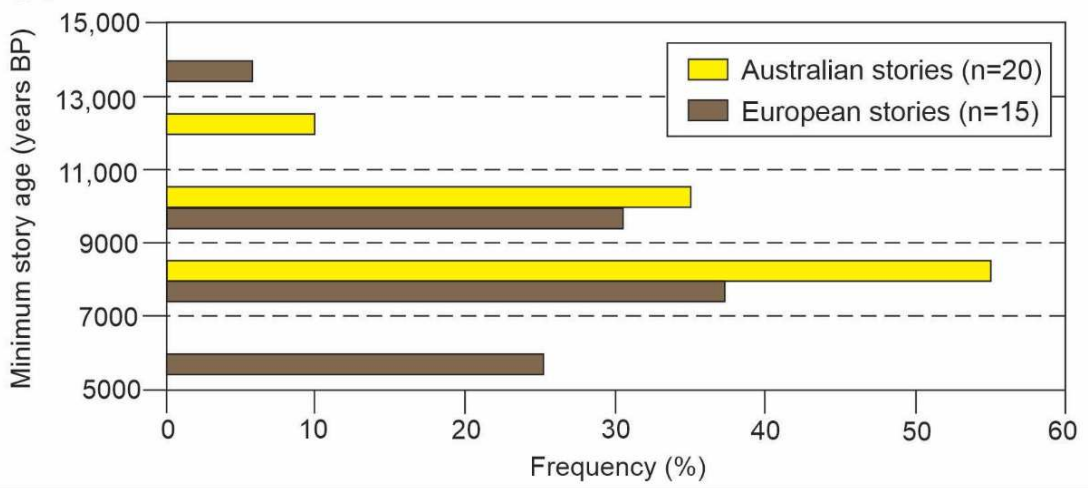

Figure 6. Comparison of European and Australia datasets. All raw data in S1 Appendix. A: Correlation between minimum story age and sea-level depth for the Europe dataset. B: Correlation between minimum story age and sea-level depth for the Australia dataset. C: Histogram comparing the age distribution of the European and Australian stories. 
In this regard, the concentration of story age minima between 7000 and 9000 BP (38\% of European stories, 55\% of Australian stories) and between 9000 and 11,000 BP (31\% of European stories, $35 \%$ of Australian stories) is of interest. While the Australian stories are all expected to be more than seven thousand years old (because this is when sea level reached its present level here), the same is not true for European stories, suggesting another factor may be in play here. Perhaps these stories both refer to the most memorable times, when sea level was rising fastest and coastal land was being lost at an unprecedented rate. Or perhaps this aspect of the analysis shows a change in the attitudes/responses of affected peoples. It is possible that anxiety about the rising sea level among affected coastal populations reached a pinnacle about 6000-7000 years ago when hugely-ambitious interventions were trialled, in the aftermath of which people became more resigned (in northwest Europe) and changed their strategy to one of accommodation of sea-level rise, expressed most likely as reductions in coastal population densities achieved by inland/overseas migration.

\section{CONCLUSIONS}

A group of 15 stories from northwest European coasts that recall land submergence is believed to encode memories of the effects of postglacial sea-level rise which have endured - in some instances - for more than 10,000 years. Together with a similar group of stories from Australia, this demonstrates the ability of pre-literate societies to amass and transmit across hundreds of generations information adjudged to be especially memorable and/or important to future survival.

The spatial distribution of these 15 European stories is closely linked to the variable history of (relative) postglacial sea-level rise within the region. The fact that no stories about submergence were found in places where submergence did not occur suggests that these stories represent authentic recollections of postglacial sea-level rise and are not cultural inventions.

While both these insights should encourage scientists to probe traditional stories ('myths and legends') more closely for meaning, with the ultimate aim of enriching and humanizing our understanding of the past, this specific dataset can also be viewed as a tool for identifying and analysing more such stories. The apparent absence of stories from the south and east coasts of Ireland, the south coast of Wales, and the north coast of Cornwall might repay more detailed research.

\section{REFERENCES}

Andrews, E 1913 Ulster Folklore Elliot Stock, London.

Anonymous 1872 Breton Legends Burns, London.

Babcock, W H 1922 Legendary Islands of the Atlantic American Geographical Society, New York.

Balfour, J A 1910 The Book of Arran Mackenzie (for Arran Society of Glasgow), Glasgow.

Ballantyne, C K \& Small, D 2019 The Last Scottish Ice Sheet. Earth and Environmental Science Transactions of the Royal Society of Edinburgh 110 93-131. 
Barber, E W \& Barber, P T 2004 When They Severed Earth from Sky: How the Human Mind Shapes Myth Princeton University Press, Princeton.

Barnett, R L, Charman, D J, Johns, C, Ward, S L, Bevan, A, Bradley, S L, Camidge, K, Fyfe, R M, Gehrels, W R, Gehrels, M J, Hatton, J, Khan, N S, Marshall, P, Maezumi, S Y, Mills, S, Mulville, J, Perez, M, Roberts, H M, Scourse, J D, Shepherd, F \& Stevens, T 2020 Nonlinear landscape and cultural response to sea-level rise. Science Advances 6 eabb6376.

Bassett, F S 1892 Sea Phantoms: or Legends and Superstitions of the Sea and of Sailors .. Morrill, Higgins and Co., Chicago.

Basso, K H 1996 Wisdom Sits in Places: Landscape and Language among the Western Apache University of New Mexico Press, Albuquerque.

Berndt, C H \& Berndt, R M 1994 The Speaking Land: Myth and Story in Aboriginal Australia Inner Traditions/Bear \& Co, Rochester, Vermont.

Borlase, W 1756 Observations on the Ancient and Present State of the Islands of Scilly W. Jackson, Oxford.

Bradley, S L, Milne, G A, Shennan, I \& Edwards, R 2011 An improved Glacial Isostatic Adjustment model for the British Isles. Journal of Quaternary Science 26 541-52.

Bromwich, R 1950 Cantre'r Gwaelod and Ker-Is. in Fox, C \& Dickens, B eds The Early Cultures of NorthWest Europe. Cambridge University Press, Cambridge.

Brousmiche, J-F 1891 Voyage dans le Finistère en 1829, 1830 et 1831 Société Académique de Brest Morvran, Brest.

Carew, R 1723 The Survey of Cornwall. And an Epistle concerning the excellencies of the English tongue Samuel Chapman, London.

Charman, D J, Johns, C, Camidge, K, Marshall, P, Mills, S, Mulville, J, Roberts, H M \& Stevens, T 2016 The Lyonesse Project: A Study of the Historic Coastal and Marine Environment of the Isles of Scilly. Cornwall Council Archaeological Unit.

Chèvremont, A 1882 Les Mouvements du Sol sur les Côtes Occidentales de la France Leroux, Paris.

Clark, C D, Hughes, A L C, Greenwood, S L, Jordan, C \& Sejrup, H P 2012 Pattern and timing of retreat of the last British-Irish Ice Sheet. Quaternary Science Reviews 44 112-46.

Cracknell, B E 2005 Outrageous Waves: Global Warming and Coastal Change in Britain through Two Thousand Years Phillimore, Chichester.

Crawford, O G S 1927 Lyonesse. Antiquity 1 5-14.

Croker, T C 1844 Fairy Legends and Traditions of the South of Ireland Lea and Blanchard, Philadelphia.

Curran, B 2000 Complete Guide to Celtic Mythology Appletree Press, Belfast.

Doan, J 1981 The legend of the sunken city in Welsh and Breton tradition. Folklore 92 77-83.

Draganits, E, Doneus, M, Gansum, T, Gustavsen, L, Nau, E, Tonning, C, Trinks, I \& Neubauer, W 2015 The late Nordic Iron Age and Viking Age royal burial site of Borre in Norway: ALS- and GPR-based landscape reconstruction and harbour location at an uplifting coastal area. Quaternary International 367 96-110.

Eigen, E 2018 On Accident: Episodes in Architecture and Landscape MIT Press, Cambridge, MA.

Elton, C 1938 Notes on the Ecological and Natural History of Pabbay, and Other Islands in the Sound of Harris, Outer Hebrides. Journal of Ecology 26 275-97.

Forester, T 1854 The Chronicle of Florence of Worcester (AD 1140 manuscript translated from the Latin) Henry Bohn, London.

Forth, G 2005 Hominids, hairy hominoids and the science of humanity. Anthropology Today 21 13-17.

Fréminville, C-P 1834 Antiquités de la Bretagne : monumens du Morbihan Lefournier, Brest.

Gaffney, V, Fitch, S \& Smith, D 2009 Europe's Lost World: The Rediscovery of Doggerland Council for British Archaeology, York. 
Galili, E, Benjamin, J, Eshed, V, Rosen, B, McCarthy, J \& Horwitz, L K 2019 A submerged 7000-year-old village and seawall demonstrate earliest known coastal defence against sea-level rise. PloS one 14.

Garcia-Artola, A, Stephan, P, Cearreta, A, Kopp, R E, Khan, N S \& Horton, B P 2018 Holocene sea-level database from the Atlantic coast of Europe. Quaternary Science Reviews 196 177-92.

Garnett, T 1811 Observations on a Tour through the Highlands and part of the Western Isles of Scotland Stockdale, London.

Gehrels, W R 2010 Late Holocene land- and sea-level changes in the British Isles: implications for future sea-level predictions. Quaternary Science Reviews 29 1648-60.

Geraghty, P 1993 Pulotu, Polynesian homeland. The Journal of the Polynesian Society 102 343-84.

Gill, W W 1932 A Second Manx Scrapbook Arrowsmith, London.

Gould, S B 1921 Brittany Methuen, London.

Gregory, J M, Griffies, S M, Hughes, C W, Lowe, J A, Church, J A, Fukumori, I, Gomez, N, Kopp, R E, Landerer, F, Le Cozannet, G, Ponte, R M, Stammer, D, Tamisiea, M E \& van de Wal, R S W 2019 Concepts and Terminology for Sea Level: Mean, Variability and Change, Both Local and Global. Surveys in Geophysics 40 1251-89.

Guyot, C 1926 La Légende de la Ville d'Ys, d'après les Anciens Textes L'Édition d'Art, Paris.

Hamacher, D W \& Goldsmith, J 2013 Aboriginal oral traditions of Australian impact craters. Journal of Astronomical History and Heritage 16 295-311.

Hardy, K, Ballin, T \& Bicket, A 2021 Rapidly changing worlds. Finding the earliest human occupations on Scotland's north-west coastline. Quaternary International 584 106-15.

Headrick, J 1807 View of the Mineralogy, Agriculture, Manufactures and Fisheries of the Island of Arran with Notices of Antiquities Willison, Edinburgh.

Henderson, G M 1905 The Fionn saga. Folk-lore 28 193-207; 353-66.

Hugo, V 1866 Les Travailleurs de la Mer Hetzel, Paris.

Jehu, T J \& Craig, R M 1926 Geology of the Outer Hebrides, Part III: North Uist and Benbecula. Transactions of the Royal Society of Edinburgh 54 467-89.

Jones, G \& Jones, T 2001 The Mabinogion Knopf, New York.

Jordan, S F, Murphy, B T, O'Reilly, S S, Doyle, K P, Williams, M D, Grey, A, Lee, S, McCaul, M V \& Kelleher, B P 2017 Mid-Holocene climate change and landscape formation in Ireland: Evidence from a geochemical investigation of a coastal peat bog. Organic Geochemistry 109 67-76.

Joyce, P W 1920 Old Celtic Romances (translated from Gaelic) Longmans, Green, London.

Kavanagh, E \& Bates, M 2019 Semantics of the Sea - stories and science along the Celtic seaboard. Internet Archaeology 53.

Kelly, L 2015 Knowledge and Power in Prehistoric Societies: Orality, Memory and the Transmission of Culture Cambridge University Press, New York.

Kelly, L 2016 The Memory Code Allen and Unwin, Sydney.

Kervran, L 1977 Brandan: Le Grand Navigateur Celte du Vle Siècle Robert Laffont, Paris.

Kingshill, S \& Westwood, J 2014 The Fabled Coast: Legends and Traditions from around the Shores of Britain and Ireland Arrow, London.

Kuchar, J, Milne, G, Hubbard, A, Patton, H, Bradley, S, Shennan, I \& Edwards, R 2012 Evaluation of a numerical model of the British-Irish ice sheet using relative sea-level data: implications for the interpretation of trimline observations. Journal of Quaternary Science 27 597-605.

Le Grand, A 1659 La Vie, Gestes, Mort et Miracles des Saints de la Bretagne Armorique Vatar, Rennes.

Maclean, C 1972 Island on the Edge of the World: The Story of St Kilda Taplinger, New York.

Manet, F 1839 De l'Etat Ancient et de l'Etat Actuel de la Baie du Mont-Saint-Michel et de Cancale, des Marais de Dol et de Châteauneuf Everat, Paris.

Martin, M 1753 A Voyage to St Kilda Browne and Davis, London. 
Matchan, E, Phillips, D, Jourdan, F \& Oostingh, K 2020 Early human occupation of southeast Australia: new insights from ${ }^{40} \mathrm{Ar} /{ }^{39} \mathrm{Ar}$ dating of young volcanoes. Geology.

Milne, G A, Gehrels, W R, Hughes, C W \& Tamisiea, M E 2009 Identifying the causes of sea-level change. Nature Geosci 2 471-78.

Murphy, G 1953 Duanaire Finn: The Book of the Lays of Fionn, Part III Irish Texts Society, Dublin.

North, F J 1957 Sunken Cities: Some legends of the coast and lakes of Wales University of Wales Press, Cardiff.

Nunn, P D 2009 Vanished Islands and Hidden Continents of the Pacific University of Hawai'i Press, Honolulu.

Nunn, P D 2016 Australian Aboriginal Traditions about Coastal Change Reconciled with Postglacial SeaLevel History: A First Synthesis. Environment and History 22 393-420.

Nunn, P D 2018 The Edge of Memory: Ancient Stories, Oral Tradition and the Post-Glacial World Bloomsbury, London.

Nunn, P D 2020 In anticipation of extirpation: how ancient peoples rationalized and responded to postglacial sea-level rise ... and why it matters. Environmental Humanities 12 113-31.

Nunn, P D 2021 Worlds in Shadow: Submerged Lands in Science, Memory and Myth Bloomsbury, London.

Nunn, P D, Lancini, L, Franks, L, Compatangelo-Soussignan, R \& McCallum, A 2019 Maar stories: how oral traditions aid understanding of maar volcanism and associated phenomena during pre-literate times. Annals of the American Association of Geographers 109 1618-31.

Nunn, P D \& Reid, N J 2016 Aboriginal memories of inundation of the Australian coast dating from more than 7000 years ago. Australian Geographer 47 11-47.

Ong, W 1982 Orality and Literacy: The Technologizing of the Word Routledge, London.

Peacock, R A 1865 On Vast Losses of Land on the Westerly Coasts of France within the Historical Period. Proceedings of the Royal Geographical Society of London 10 329-38.

Peltier, W R, Argus, D F \& Drummond, R 2015 Space geodesy constrains ice age terminal deglaciation: The global ICE-6G_C (VM5a) model. Journal of Geophysical Research-Solid Earth 120 450-87.

Piccardi, L \& Masse, W B (Eds.) (2007) Myth and Geology, London, Geological Society of London.

Plees, W 1817 An Account of the Island of Jersey Baker, Southampton.

Poingdestre, J 1889 Caesarea; or, A discourse of the Island of Jersey Le Feuvre, St Helier.

Porr, M 2018 Country and Relational Ontology in the Kimberley, Northwest Australia: Implications for Understanding and Representing Archaeological Evidence. Cambridge Archaeological Journal 28 1-15.

Purzycki, B G, Apicella, C, Atkinson, Q D, Cohen, E, McNamara, R A, Willard, A K, Xygalatas, D, Norenzayan, A \& Henrich, J 2016 Moralistic gods, supernatural punishment and the expansion of human sociality. Nature 530 327-+.

Raimbault, C, Duperret, A, Regard, V, Molliex, S, Wyns, R, Authemayou, C \& Le Gall, B 2018 Quaternary geomorphological evolution of a granitic shore platform constrained by in situ Be-10 concentrations, Penmarc'h, SW Brittany, France. Marine Geology 395 33-47.

Reclus, E 1877 Nouvelle Géographie Universelle, La Terre et Les Hommes Hachette, Paris.

Roberts, A L, Mollenmans, A, Rigney, L I \& Bailey, G 2019 Marine Transgression, Aboriginal Narratives and the Creation of Yorke Peninsula/Guuranda, South Australia. Journal of Island \& Coastal Archaeology.

Rodwell, W 1996 Les Écréhous Société Jersaise, Jersey.

Ross, M C 1986 Australian Aboriginal oral traditions. Oral Tradition 1 231-71.

Roughsey, D 1971 Moon And Rainbow: the Autobiography of an Aboriginal Reed, Sydney.

Sébillot, P 1899 Légendes Locales de la Haute-Bretagne Société des Bibliophiles Bretons, Nantes.

Sébillot, P 1905 Le Folk-Lore de la France: La Mer et Les Eaux Douces Guimoto, Paris. 
Shennan, I, Bradley, S L \& Edwards, R 2018 Relative sea-level changes and crustal movements in Britain and Ireland since the Last Glacial Maximum. Quaternary Science Reviews 188 143-59.

Shennan, I, Milne, G \& Bradley, S 2012 Late Holocene vertical land motion and relative sea-level changes: lessons from the British Isles. Journal of Quaternary Science 27 64-70.

Sinclair, J 1794 The Statistical Account of Scotland William Creech, Edinburgh.

Smith, D E, Davies, M H, Brooks, C L, Mighall, T M, Dawson, S, Rea, B R, Jordan, J T \& Holloway, L K 2010 Holocene relative sea levels and related prehistoric activity in the Forth lowland, Scotland, United Kingdom. Quaternary Science Reviews 29 2382-410.

Spence, L 1917 Legends and Romances of Brittany Stokes, New York.

Stewart, A M, Keith, D \& Scottie, J 2004 Caribou crossings and cultural meanings: Placing traditional knowledge and archaeology in context in an Inuit landscape. Journal of Archaeological Method and Theory 11 183-211.

Sugiyama, M S, Mendoza, M \& Quiroz, I 2020 Ethnobotanical Knowledge Encoded in Weenhayek Oral Tradition. Journal of Ethnobiology 40 39-55.

Sultan, N, Cochonat, P, Foucher, J \& Mienert, J 2004 Effect of gas hydrates melting on seafloor slope instability. Marine Geology 213 379-401.

Tonkin, E 1992 Narrating Our Pasts: The Social Construction of Oral History Cambridge University Press, New York.

Tupper, F B 1854 History of Guernsey and its Bailiwick Barbet, Guernsey.

Vallaux, C 1903 Sur les oscillations des côtes occidentales de la Bretagne. Annales De Geographie 61 1930.

Vansina, J 1985 Oral Traditions as History University of Wisconsin Press, Madison.

Vitaliano, D 1973 Legends of the Earth: their Geologic Origins Indiana University Press, Bloomington, Indiana.

Welch, J 1836 A Six Days' Tour through The Isle of Man Dillon, London.

Westropp, T J 1908 Ancient remains near Lehinch, Co. Clare. Journal of the Limerick Field Club 3 192-213.

Westropp, T J 1912-1913 Brasil and the Legendary Islands of the North Atlantic. Proceedings of the Royal Irish Academy 30 223-360.

Wilkie, B, Cahir, F \& Clark, I D 2020 Volcanism in Aboriginal Australian oral traditions: Ethnographic evidence from the Newer Volcanics Province. Journal of Volcanology and Geothermal Research 403.

Wilson, J M 1870 The Imperial Gazetteer of England and Wales Fullarton, Edinburgh.

Wood-Martin, W G 1882 History of Sligo: County and Town Hodges \& Figgis, Dublin.

Wood-Martin, W G 1902 Traces of the Elder Faiths of Ireland: A Folklore Sketch Longmans, Green, London. 